\title{
UN Peace operations and conflicting legitimacies
}

Article

Accepted Version

von Billerbeck, S. B. K. (2017) UN Peace operations and conflicting legitimacies. Journal of Intervention and Statebuilding, 11 (3). pp. 286-305. ISSN 1750-2985 doi: https://doi.org/10.1080/17502977.2017.1353751 Available at https://centaur.reading.ac.uk/71251/

It is advisable to refer to the publisher's version if you intend to cite from the work. See Guidance on citing.

To link to this article DOI: http://dx.doi.org/10.1080/17502977.2017.1353751

Publisher: Taylor and Francis

All outputs in CentAUR are protected by Intellectual Property Rights law, including copyright law. Copyright and IPR is retained by the creators or other copyright holders. Terms and conditions for use of this material are defined in the End User Agreement.

\section{www.reading.ac.uk/centaur}

\section{CentAUR}

Central Archive at the University of Reading

Reading's research outputs online 


\title{
UN Peace Operations and Conflicting Legitimacies
}

\author{
Sarah B. K. von Billerbeck \\ s.b.k.vonbillerbeck@reading.ac.uk \\ Department of Politics and International Relations \\ University of Reading \\ Edith Morely Building, Whiteknights Campus \\ Reading, RG6 6AA
}

\begin{abstract}
Analyses of UN peacekeeping increasingly consider legitimacy a key factor for success, conceiving of it as a resource that operations should seek and use in the pursuit of their goals. However, these analyses rarely break down legitimacy by source. Because the UN is an organization with multiple identities and duties however, different legitimacy sources - in particular output and procedural legitimacy — and the UN's corresponding legitimation practices come into conflict in the context of peacekeeping. Drawing on a range of examples and a specific case of the UN mission in Congo, this article argues that looking at different legitimacy sources and linking them to the institutional identity of the UN is thus critical and it shows how the UN's in contradictory legitimation practices can reduce overall legitimacy perceptions.
\end{abstract}

\section{Keywords}

United Nations, peacekeeping, legitimacy, legitimation, self-determination, effectiveness

\section{Introduction}

Analyses and understandings of UN peacekeeping have increasingly considered the legitimacy (or illegitimacy) of such operations. On the one hand, scholars and practitioners imply that there is a moral requirement to justify the presence of a peacekeeping mission to the populations of host countries, countries that risk the lives of their troops in UN missions, and donor governments and their taxpayers who foot the bill for these operations. ${ }^{1}$ On the other hand, legitimacy is frequently cited as critical to the operational effectiveness of peacekeeping and therefore understood as something that has practical utility in the realization of peace and stability in war-torn states. The 2008 United Nations Peacekeeping Operations: Principles and Guidelines (known as the Capstone Doctrine), for example, calls legitimacy a key 'success factor,' declaring that, 'in order to succeed, United Nations peace operations need to be seen as legitimate' (36). Similarly, Mark Suchman $(1995,576)$ calls legitimacy 'an operational resource that organizations...employ in pursuit of their goals' (italics in original).

As the literature exploring the link between UN peacekeeping and legitimacy expands, increasing attention has also been paid to the various audiences of legitimacy in the context of peacekeeping, with a particular focus on the need for local populations to view the UN as legitimate (Coleman 2017, 2007; Donais 2009; Pouligny 2006; Whalan 2017). What has received less attention, however, is how different sources of legitimacy affect judgments of legitimacy in peacekeeping, whether from local populations or other audiences, such as the Security Council or the governments and populations of troop contributing countries (TCCs). Indeed, assessments of the legitimacy of UN peace operations often do not take into account any subdivision of legitimacy, instead focusing simply on whether the interventions are or are 
not legitimate in an absolute sense or focusing on only one source of legitimacy (UN 2008; Gow and Dandeker 1995; Mersiades 2006). Because this undifferentiated approach to legitimacy leaves out the source of legitimacy, however, it fails to acknowledge that legitimacy is not a cohesive concept, but instead one that is multifaceted, contested, and conceived of in different ways by both the UN and those with whom it interacts in peacekeeping. This renders most pronouncements on the legitimacy of UN peace operations at best over-simplistic and at worst misleading.

In this article, I argue that looking at different legitimacy sources - in particular output and procedural legitimacy - and linking them to the institutional identity of the UN is critical, because these different legitimacies come into conflict in the context of UN peace operations. More specifically, the UN has multiple identities in peacekeeping: it is both an operational actor that participates concretely in stabilization and peace consolidation, deploying troops, materials, and resources to war-torn countries, and it is a normative actor that embodies and projects norms and principles at the international level (von Billerbeck 2016). The 'operational UN' derives legitimacy primarily from outputs - that is, from what it achieves - while the 'normative UN' derives legitimacy primarily from procedural - that is, from the way in which it behaves. However, in peacekeeping, the efficient achievement of outputs and the compliance with institutional norms and principles can conflict, thus forcing the UN into a situation where it must 'choose between' output and procedural legitimacy. The contradiction between these two sources of legitimacy, and more broadly between the normative and operational identities of the UN, leads to contradictions between the UN's discourse and its practices in peacekeeping, ultimately reducing overall judgments of its legitimacy by its various audiences.

The first part of this article is conceptual, applying theories and understandings of legitimacy, legitimation, and organizational behaviour to UN peacekeeping operations. I examine legitimacy and legitimation and the ways in which the UN's multiple identities dictate different sources of legitimacy in peacekeeping, and as mentioned, I find that two sources in particular are relevant: procedural legitimacy and output legitimacy. I then turn to an empirical examination of the legitimation practices of UN peacekeeping operations, showing how the organization attempts to balance between these two legitimacies and how this results in contradictions between the UN's discourse and its practices. I draw examples from three UN peacekeeping operations to illustrate my points, including those in the Democratic Republic of Congo, East Timor, and Liberia. ${ }^{2}$ I then use the case of Congo specifically to show how these contradictions render the UN highly inconsistent and reduce its legitimacy in the eyes of one of the UN's legitimacy audiences, the host country population. ${ }^{3}$

The data for the empirical sections of this article are drawn from primary documents, secondary literature on the missions, and semi-structured interviews with UN staff and with local actors in Congo. ${ }^{4}$ The missions in Congo, East Timor, and Liberia were selected according to two criteria. First, they are representative of different 'styles' of contemporary peacekeeping, enabling me to widen the applicability of my findings across peacekeeping. The missions in Congo and Liberia are among the UN's largest and operate(d) in conditions of internecine, multi-party conflicts and ongoing fighting; the mission in East Timor was an international transitional administration and thus usurped executive power from the government for many aspects of the country's political transition, but did not, at least initially, encounter such extreme insecurity as in the other two settings. Second and crucially, these cases vary on the degree of intrusion by the UN and thus the UN faced different challenges in terms of justifying and legitimating its presence to the host country population, the particular legitimacy audience that I focus on. While this article does not offer an in-depth empirical analysis of legitimacy judgments by all potential audiences in particular settings-a 
worthy topic for future research - it provides a general mapping of contradictory legitimation practices across a sample of missions and of how legitimacy audiences may view these inconsistencies, thus enabling broader conclusions about the variability of legitimacy in contexts of post-conflict peacekeeping and about the UN's behaviour more generally.

\section{Sources of Legitimacy}

Legitimacy is traditionally conceived of as a status ascribed by one actor to another based on shared understandings of what is appropriate, good, or correct; it is often thought to characterize a relationship between ruler and ruled and serves to justify the exercise of power by the former towards the latter (Coicaud 2002; Gilley 2009; Hurd 2007; Franck 1990; Clark 2005; Beetham 1991; Mulligan 2005). Coleman (2007) adds that legitimacy can apply both to actions and actors. As noted in the Introduction to this Special Issue, however, these conceptions, which were largely developed in state-based analytical frameworks, neglect the fleeting nature of power, the changeability of relations and alliances, the proliferation of potential audiences for legitimacy, and the lack of agreement on what constitute appropriate, good, or correct behaviour in conflict and post-conflict settings (von Billerbeck and Gippert 2017).

In addition to the questionable applicability of common understandings of legitimacy to conflict and post-conflict contexts, there has been a failure to consider different sources of legitimacy in peacekeeping. While many typologies have been posited by scholars, four sources are particularly relevant here. ${ }^{5}$ First, procedural legitimacy focuses on how an actor or organization achieves its stated goals and holds that the processes that lead to outputs should adhere to accepted and shared principles and norms (Clark 2005; Steffek 2003). In the case of peacekeeping, this entails compliance on the part of the UN with institutional principles and norms in the conduct of its activities in host countries. Second, output legitimacy stems from performance and effectiveness, stressing that whether and to what degree an entity achieves its stated goals is the source of legitimacy (Clark, 2005; Scharpf 1999; Suchman 1995). In the case of peacekeeping, output legitimacy relates to whether the mission delivers on key mandated tasks, such as security, protection of civilians, and political reform, and it is relatively more quantifiable than procedural legitimacy. Third, source legitimacy focuses on the mandate, capacity, and constitution of an entity. In peacekeeping, this legitimacy relates to the mission's initial claim to authority on arrival, usually enshrined in its mandate, and to judgments at the outset about whether the mission is considered capable of achieving its goals (Whalan 2013, 65). In the case of UN peacekeeping, of particular relevance to source legitimacy is the fact that the UN is a universal intergovernmental organization comprising nearly all the states in the international system, a fact that bestows it with a unique source legitimacy when it is first tasked with peacekeeping. Fourth, legal legitimacy distinguishes legitimacy from legality in order to highlight that actions can be legitimate without being strictly legal, as, for example, the NATO bombing of Kosovo in 1999 (Roberts 2003). In UN peacekeeping, mandates, Status of Forces Agreements, and other Memoranda of Understanding between the UN and the host country government constitute the bases for the legal legitimacy of the mission.

While these various legitimacy sources are all relevant to some degree in peacekeeping, the first two - procedural and output - are the most important for my analysis. Source legitimacy and legal legitimacy provide an important basis for a mission to be initially accepted in a host country, but they are less useful in discovering how legitimacy is created, endures, and evolves over the life of a peacekeeping operation. More specifically, the UN's universal membership and global nature provide a legitimacy that buttresses its claims to be the correct organization for the job, but it does not provide the UN with ongoing grounds for that claim. Indeed, a peacekeeping mission would be hard pressed to continue invoking that 
unchanging aspect of its identity in order to generate renewed legitimacy over time. Likewise, though mandates and other legal instruments are renewed on a regular basis during the life of a peacekeeping operation, because they are concluded exclusively with the host government and not with any wider segment of the population, the legal legitimacy they bestow presents only a partial picture of overall legitimacy assessments. By contrast, how the UN behaves in peacekeeping and what it achieves constitute ongoing sources of legitimacy that reaffirm for a wide audience the UN's rightness for the job and ability to continue delivering tangible results. This line of argument blurs the distinction between the legitimacy of an actor and its actions. An actor's identity must be demonstrated, affirmed, and reaffirmed on a continuous basis for it to remain legitimate, and this must be done through actions that show consistency, cohesion, and unity of purpose and principle over time. In peacekeeping, the UN as an actor may be able to remain legitimate even where it takes illegitimate actions, but only if doing so is the exception rather than the rule; persistent illegitimate action would certainly reduce the overall legitimacy of the UN as an intervening force.

However, with a few exceptions, few analysis of peacekeeping take into account either the distinction between what an actor does and what an actor is, nor of any other subdivision of legitimacy (Whalan 2013; Mersiades 2005; Lipson 2007). Naturally, since different actors will value different sources of legitimacy, an understanding of those sources is key, both to how legitimacy judgments are made by various actors and to how the UN seeks and claims legitimacy - that is, legitimation. Indeed, the recognition that legitimacy is important to peacekeeping has led the UN to engage in a variety of legitimation practices aimed at boosting legitimacy in the eyes of a number of audiences, but without attention to how different legitimation practices complement or contradict one another or what types of legitimacy are valued by different audiences.

Most understandings of legitimation focus on the need to justify the exercise of power as a way of securing the consent of those subject to it. Legitimation is thus thought to entail actions that validate an actor's claim to authority by ensuring that it is subject to shared principles and is exercised in the interest of shared goals (Beetham 1991); as such, legitimation validates or reinforces an actor's identity and in particular its identity as a power holder (Barker 2001). Seeking the consent of the governed is thus not only a pursuit of their acquiescence to specific actions or practices of authority, but an agreement, implicit or explicit and renewed on an ongoing basis, that the actor in question has the right to rule or to exercise power in general, as just described.

This understanding of legitimation, however, assumes that the actor in question has a clear and cohesive identity that can be recognized and validated. While this may be true in some instances, in the case of UN peace operations, the organization's identity is not unitary but multifaceted, thus complicating the organization's legitimation efforts. As described, the $\mathrm{UN}$ is at once a normative actor dedicated to the development and dissemination of norms and principles and an operational actor participating in concrete ways in the management of conflicts. While there is nothing intrinsic about these different identities that makes them oppositional, in the context of peace operations, they often dictate different goals and obligations, different ways of behaving, and different sources of legitimacy that can conflict with one another. Accordingly, in seeking to legitimate one side of its identity, the UN may de-legitimize another, thus imperiling overall judgments of legitimacy.

\section{Contradictory Goals in Peacekeeping}

Much recent scholarship on peacekeeping has highlighted the fact that it is a practice marked by contradictions and incongruities, in what has come to be called 'dilemma analysis,' where peacekeeping practitioners find themselves in paradoxical situations relating 
to dependency, duration, and participation (Paris and Sisk 2009). For example, deployment in large numbers and the use of coercive measures may stop fighting or human rights abuses, but may create dependency on the UN for continued security. Similarly, the tasks that contemporary multidimensional peacekeeping proposes to undertake-such as building of resilient political institutions, security sector reform, and reconciliation between conflict parties - are long-term projects, the longer the UN remains in a country, the greater the risk of opposition and even aggression towards it among the local population. The UN may likewise be obliged to interact with actors responsible for war crimes, abuses against civilians, or corruption and fraud in order to bring about a cessation of hostilities, but doing so may be seen as an implicit condoning of their activities, and thus derail efforts to secure post-war justice and reconciliation.

These dilemmas can usually be attributed to the broader tension between two imperatives facing the UN: that of upholding norms relating to self-determination and noninterference that are enshrined in the organization's Charter and that of maintaining international peace and security. ${ }^{6}$ While the UN has always supported the principle of selfdetermination, more recently, it has come to be seen as a key determinant of success in the UN's post-conflict peacekeeping activities because it is believed to render those activities more legitimate. If the UN designs, implements, and manages post-conflict reconstruction, it will be viewed as neo-imperial and out of touch with local needs and desires, and hence illegitimate. The activities described earlier, such as institution building and reconciliation, are processes that are usually off-limits to external interference and are constitutive of a country's self-determination; their management by outside actors thus represents a violation of the UN's stated principles (Saul 2011). By contrast, peacekeeping operations that build the capacity of local actors to envision, design, and implement their own peace consolidation and reconstruction processes; that remain temporary in nature; and that ensure wide participation and local ownership are more acceptable and appropriate. ${ }^{7}$

At the same time, as much as the UN is mandated to uphold self-determination, it is equally tasked with the maintenance of international peace and security, and thus it is obliged to take action - even intrusive action - where these are deemed at risk. Indeed, many contend that a UN peacekeeping mission is only deployed because local actors failed to manage their societal disputes independently without recourse to violence, indicating that a violation of self-determination may be required in order to engender the stability, resilience and reconciliation for which the UN strives (Chesterman 2007, 7). The Capstone Doctrine, recognizes that 'multi-dimensional United Nations peacekeeping operation[s] may be obliged, in the short-term, to take on important state-like functions, such as the provision of security and the maintenance of public order' (UN 2008, 40). Yet, as Saul $(2011,174)$ notes, 'the level of international involvement that is necessary to make a significant difference is likely to conflict with the principle of self-determination.'

In this way, two of the UN's primary roles - that of a norm developer and diffuser and that of the main international organization charged with international peace and securitycome in to conflict in the context of peacekeeping operations. ${ }^{8}$ Deep intrusion and a degree of external imposition may be the only way the UN can effectively build peace, but will entail a violation of its normative obligation to uphold and exemplify the values and principles enshrined in its Charter.

\section{Multiple Identities and Conflicting Legitimacies}

This conflict between the UN's responsibilities towards peace and security and towards the principles of self-determination and non-imposition are reflective of the fact that the UN as an organization has both normative and operational identities (Lipson 2007). Importantly, different sources of legitimacy matter for these different identities. While the 
'normative UN' is concerned with appropriate procedure and behaving in ways that respect institutional principles (Lipson 2007, 12), the 'operational UN' needs to show results and to demonstrate that it has delivered concrete and quantifiable outputs in the interests of international peace and security, and if it does not, '[its] lack of effectiveness injures [its] legitimacy' (Barnett and Finnemore 2004, 168). ${ }^{9}$ In short, the former derives legitimacy from procedure and the latter from output.

Not only do the UN's identities imply different sources of legitimacy in the context of its peace operations, but procedural and output legitimacy also imply different practices of legitimation. One of the main ways in which actors seek procedural legitimacy is through discourse, that is, declarations of adherence to particular norms and principles relating to modes of behaviour. According to Steffek (2003, 261-4), the act of 'giving reasons' enables actors or institutions to rationally convince others of their legitimacy, rather than rely on the acceptance of their authority on a theoretical or conjectural basis. Accordingly, this kind of legitimation often entails acts of communication and representation that employ the language of and attempt to demonstrate commitment to values, norms, and appropriate behaviour (Hurd 2001, 2007; Barker 2001).

By contrast, output legitimacy is generated and affirmed through the efficient delivery of demonstrable and tangible results usually in the short term, and thus acts of legitimation and judgments of legitimacy are less reliant on discourse or symbolism, and are, as mentioned above, relatively more quantifiable and visible. They often focus on projects where results come about quickly, rather than longer-term, slower processes of change. ${ }^{10} \mathrm{~A}$ strict dichotomy is of course over-simplistic - concrete results need to be advertised and communicated and will have normative content and discourse will refer to targets and deliverables. Still, the UN's legitimation practices in peacekeeping have two overall thruststhe discursive and the practical — which are geared towards the generation of procedural and output legitimacy respectively.

As discussed, however, in UN peace operations, norm compliance and operational effectiveness may clash. Accordingly, if legitimation entails, at least in part, efforts to reaffirm an institutional identity, how can an organization with two identities that come into conflict simultaneously reaffirm them? How can the UN declare and demonstrate adherence to principles when its actions may tell a different story? Should the UN prioritize efforts towards procedural legitimacy or towards output legitimacy? What type of legitimacy matters most to the UN's various legitimacy audiences in peacekeeping?

Barnett and Finnemore (2004) have suggested that international organizations often emphasize compliance with and advocacy for rules, principles, and norms above the achievement of concrete results. The UN in particular is often looked to for leadership on normative or ethical matters and its ongoing adherence to and promotion of international principles and values has become one of the main ways in which it justifies its continued relevance and authority (Claude 1966; Hurd 2007; Rubinstein 2008). This prioritization of norms and principles over the delivery of quantifiable outputs can also be explained as behaviour motivated by a 'logic of appropriateness' rather than a 'logic of expected consequences' (March and Olsen 1998). According to the former, ideas and identities better explain the motivations of actors in the international system; according to the latter, material factors, preferences, and interests constitute actors' key motivations. Barnett and Finnemore $(2004,39)$ call this greater emphasis on upholding norms and principles relative to the achievement of operational targets a type of 'dysfunction.' They suggest that organizations that do this prize a kind of 'symbolic legitimacy' of the kind described above over efficiency, cost-effectiveness, and speed in the achievement of targets - in other words, they value procedural legitimacy over output legitimacy. 
However, particularly in peacekeeping operations, where its conflicting institutional imperatives are laid bare, the UN rarely sacrifices its operational objectives to normative processes in the way that Barnett and Finnemore suggest it may, and instead it attempts to balance between them. This is not because the UN vacillates between different logics of action, but because it views both of these imperatives - the concrete achievement of security tasks and delivery of outputs and the preservation of host country self-determination - as important sources of legitimacy (see Coleman, 2017). As Lipson $(2007,13)$ argues, '[t]he UN is not a purely political organization, but also must produce action.'

\section{Contradictory Legitimation Practices}

The outcome of this balancing act, however, is that there are often contradictions between the UN's peacekeeping discourse and practices (von Billerbeck 2016). By simultaneously seeking to maintain host country self-determination and intrude deeply enough to have a material impact upon political stability and security, the UN ends up engaging in inconsistent and incongruous legitimation practices. Indeed, it often engages in activities that aim to achieve visible outputs with a view to signaling its efficiency and effectiveness and thus gain legitimacy based on performance, but with little regard for the building of national capacities, keeping missions temporary, and including a broad range of actors in its activities. At the same time, it heavily emphasizes the importance of these latter points in its discourse in a bid to project its dedication to the self-determination of the host country and the imperative to minimize interference and imposition. This occurs particularly in relation to the dilemma areas mentioned above-dependency, duration, and participation.

First, the UN will at times take forceful action with regards to the security situation on a unilateral basis, without simultaneously training national actors to take up those security tasks later. In Congo, MONUC initiated the International Security and Stabilization Support Strategy (ISSSS) in 2008 in a bid to improve security, extend state authority, ensure safe return and recovery for displaced persons, and deter further fighting in the east of the country, which remained highly unstable long after the formal end of the conflict. However, the initial plans were 'sketche[d] on the back of an envelope' by senior mission staff with no input from national actors; one staff member recalled that the overall attitude within the UN was 'participation lite,' with importance placed instead on demonstrating decisive improvements in security to the government, host population, and donors so as to retain or increase their support of the mission. ${ }^{11}$ Another staff member closely working on the ISSSS asserted that the UN's 'objective... is not to develop capacity in the longer term, it is to restore security, open roads, get things going again. ${ }^{12}$ Several others reiterated the importance of delivering peace dividends to the population that are 'tangible" ${ }^{13}$ and 'quick. ${ }^{14} \mathrm{UN}$ staff told a similar story in Liberia, with one describing the most important goals of the mission as ' $[\mathrm{g}]$ et the arms away from the thugs, break down the structures, and try to get a few peace dividends on the ground' but 'not...[build] capacity.',

Even where the UN does undertake capacity building, it can often be with an eye to boosting demonstrable targets rapidly, rather than boosting self-determination. In Liberia, for example, UN Police (UNPOL) trained members of the new Liberian National Police beginning in 2004, with an ambitious target of 3,500 officers trained and deployed by 2007. Not only was the curriculum designed without much Liberian input, the trainings themselves were initially just three months long (though this was later extended to six months) (Friedman 2011). These actions all prioritize reaching targets above host country self-determination, in a bid to demonstrate visible successes quickly and satisfy a number of legitimacy audiences, including the host country population, donors, and others. As one senior DPKO official noted, '[sometimes] you pick a fight you can win in order to signal the end of the rule of the gun and the beginning of the rule of law; but it's theater, show, it's about signaling., 16 
At the same time, the UN's discourse tends to put a heavy emphasis on building national capacity in a bid to convince others through discourse of the fact that it is approaching peacekeeping in the 'appropriate' way, a way that puts self-determination first and takes the enhancement of national capacities as a priority. The recently published Report of the High-Level Independent Panel on Peace Operations (known as HIPPO) stresses the need to 'build future capacities to better prevent the scourge of war' (UN 2015, 32), and both this report and the earlier Capstone Doctrine (UN 2008) highlight the importance of training efforts, particularly in the security sector. The discursive emphasis here, is on boosting the capacities of national actors so that peacebuilding and reconstruction can be self-determined, with little said about quantifiable targets. This too is a form of signaling, but instead it uses discourse to demonstrate the UN's commitment to appropriate and nationally-oriented procedures, thus contradicting its efforts to gain legitimacy based on short-term outputs achieved with little or no regard for national capacities.

Second, though peacekeeping is by definition temporary, many operations remain in place for protracted periods due to, as mentioned, the long-term nature of many of the activities they undertake, and the extended presence of the UN over time often leads to resentment on the part of the host government and population as well as intensifies any dependence that may have developed. David Edelstein $(2009,83)$ refers to this as an 'obsolescing welcome,' in which 'national groups that are accustomed to governing themselves ...bridle at living under the control of foreign political and military organizations'; at the same time, he notes, they often remain reliant on those very foreign organizations for security and stability.

For example, the UN's presence in East Timor was intended to be a temporary phenomenon, providing assistance in the transition to full independence; yet the country ended up seeing a succession of missions and follow-on missions that extended the UN's presence in the country until $2012 .{ }^{17}$ While this underlines the fact that major political transitions and post-conflict reconstruction usually occur in a stop-start way rather than as a linear progression, it also underlines the fact that the country was in many ways still reliant on the UN for certain functions, such as security, well into its transitional period. ${ }^{18}$ MONUC and UNMIL are also both examples of multidimensional peacekeeping operations that have remained in place for over a decade each and where the population is weary of their presence but still dependent on it, at least partly, for security. ${ }^{19}$ As one former senior UN military commander noted, 'Liberia [is] still fully supported by the UN-if the UN left, [Liberia] would revert to conflict. ${ }^{20}$ A senior DPKO official noted that having the mission in Congo '[stay] indefinitely [would be] better for peace,' specifying that leaving prematurely would cause the UN to lose credibility as most visible improvements in security would likely dissipate. $^{21}$

However, despite the fact that many UN missions have turned out to be relatively long-lived and the countries that host them show little readiness for their departure, the UN's discourse continues to emphasize the temporary nature of peacekeeping and the need for national actors to play a leading role. The Best Practices Unit's Handbook on United Nations Multidimensional Peacekeeping Operations (UN 2003, 112) describes UN missions as having 'short life spans.' The Capstone Doctrine (UN 2008) echoes this, noting that peacekeeping operations are 'neither designed nor equipped to engage in longer-term institution and capacity-building efforts' (28) and that the role of the UN should 'diminish quickly' (37). Similarly, the Report of the Secretary-General on Peacebuilding in the Immediate Aftermath of Conflict (UN 2009, 15) asserts that '[u]sing and supporting national capacity should be the first preference' and the completion of peacebuilding tasks by the UN something that should occur 'on a short-term and limited basis.' In this way, despite the growing longevity of most contemporary peacekeeping operations, the UN insists 
discursively that missions are not only temporary, but short-lived, a stance that fits with its emphasis on keeping intervention and imposition to a minimum.

Third, the UN may interact in the short term with actors alleged to have committed or condoned atrocities, human rights abuses, or war crimes in the interests of consolidating a fragile peace agreement or avoiding a return to violence, but in the long term it may then attempt to back off from relationships with such actors. In Congo, for example, the UN facilitated an agreement between Peter Karim Udaga, leader of the Front des Nationalistes et des Intégrationnistes (FNI) rebel group in the northeastern district of Ituri, and the Congolese government in 2006. Despite allegations of FNI involvement in atrocities, abuses against civilians, and child recruitment, part of the deal involved granting Karim the rank of colonel in the Forces Armées de la République Démocratique du Congo (FARDC). Such bargains are considered necessary in order to demonstrate progress towards ending conflict and thus the UN's contribution to peace and stability. ${ }^{22}$ Nevertheless, while these deals may help achieve immediate stabilization goals, they certainly do little to further the cause of justice. Indeed, UN staff are quick to declare their refusal to interact with anyone implicated in atrocities and the need to end impunity and bring human rights abusers to justice (see UN 2004), with one noting that 'if you deal with...thugs, you lose your moral standing. ${ }^{23}$

Relatedly, in most security related matters, MONUC found it generally more expedient to work with members of the FARDC who had been officers in the Forces Armées Congolaises (FAC) and Forces Armées Zairoises (FAZ) during the Mobutu era and pre-war years rather than with members of more recently-formed rebel groups. While the latter often had minimal training or general education, the former had often had advanced military tuition in the US, Europe, and elsewhere prior to the wars, and MONUC staff admitted that they made better partners for the mission due to their knowledge of military strategy, understanding of the hierarchies, logistics, and management of armed forces, and enhanced ability to operate jointly with other national militaries - in short, their ability to help the UN achieve its stated objectives. $^{24}$

Similarly, in spite of its heavy emphasis on local ownership, the UN may consult with national actors through meetings and joint initiatives, but then act unilaterally, with little substantive input from national actors or in consultation with only a few elite partners (von Billerbeck 2016). For example, the UN often conducts assessments in the early stages of missions. While these Joint Assessment Missions (JAMs) or Post-Conflict Needs Assessments (PCNAs) have become longer, more inclusive processes, most staff admit that they are largely an effort to get national actors 'on board' with what the UN wants, rather than a true negotiation to assess needs and capacities and develop priorities and objectives from scratch. ${ }^{25}$ Likewise, though the writing of the post-independence constitution in East Timor was ostensibly led by the Timorese themselves, there was heavy UN influence, and one UN staff member characterized Timorese involvement as 'a pretense. ${ }^{, 26}$ Another recalled, 'sometimes the prime minister [in East Timor] sign[ed] this...project, so it's their project. But we have drafted it, word for word. ${ }^{27}$ These staff members admitted that the intent in taking this approach was to get results quickly because insisting on coimplementation with local actors 'slowed everything down to no end. ${ }^{28}$

In the case of Timor, the UN's intrusiveness and dominance in the country led to widespread resentment against the organization, prompting it to introduce a policy of 'Timorization' to include more national actors in key political decisions. This is particularly notable because UNTAET was initially welcomed with relative goodwill in the country, due to the fact that it was not there to negotiate between former warring parties, but to help a relatively cohesive post-independence government get on its feet. ${ }^{29}$ Even in what could be characterized as among the most favorable conditions the UN is likely to encounter when deploying to a country, resentment among the political elites at the abrogation of self- 
determination and the high level of intrusion, which run contrary to what the UN declares as guiding principles, developed quickly. And even once Timorization was introduced, many question how much it actually did to include the Timorese in a substantive way in the taking of key decisions and implementation of key tasks. McDowell $(2006,187)$ notes that many considered Timorization to consist only of 'empty gestures.' It appears that it may have been, at least partly, a discursive tool intended to allay national concerns and generate procedural legitimacy.

Relatedly, the UN often emphasizes democracy, transparency, and inclusivity in discourse, yet it only sometimes behaves in line with those principles, often engaging instead in closed decision-making, excluding particular groups, and behaving in an opaque manner. This is done not out of a rejection of the principles of democracy, transparency, and inclusivity or a lack of belief in their importance, but instead out of an interest in achieving results as quickly, efficiently, and cost-effectively as possible in order to maximize output legitimacy. The HIPPO report (UN 2015, 72) admirably declares that, '[u]nnecessary formalism, process and bureaucracy should give way to a new commitment to putting in place streamlined processes and more transparent procedures and decision-making'; the UN's discourse thus clearly stresses the need for principled procedures. Similarly, the report (UN $2015,25)$ emphasizes the need for 'inclusive and participatory peace processes,' echoing the Capstone Doctrine's earlier call for 'wide representation, inclusiveness, and gender considerations' (UN 2008, 39).

Staff admit, however, that in practice they often sacrifice these principles for the sake of hitting their quantifiable targets. One MONUC official conceded that, 'we just do things for [local actors] sometimes because there is a pressure to deliver. ${ }^{, 30}$ Another noted that peacekeeping requires 'speed and urgency' and so the UN should only involve actors where they do not impinge upon the ability to quickly reach targets. ${ }^{31}$ 'Cutting normative corners,' then, and both disregarding the extent of host country self-determination and deepening the degree of UN intrusion become acceptable as ways of boosting output legitimacy, even if doing so comes at the expense of procedural legitimacy.

\section{Implications for Legitimacy Judgments}

Evidently, there are clashes between the UN's discourse and its actions in peacekeeping, where it declares its dedication to a particular set of principles, but often behaves in the interests of a different set of objectives, and the line between its procedural and output legitimation practices is thus blurred. Nils Brunsson (2002) calls this 'organized hypocrisy,' a dynamic that Lipson $(2007,5)$ describes as one 'in which organizations respond to conflicting pressures in external environments through contradictory actions and statements.' Stephen Krasner $(1999,66)$ asserts that organized hypocrisy occurs when there is a clash between the logic of appropriateness and the logic of consequences, and he states that actors 'must honor, perhaps only in talk, certain norms but at the same time act in ways that violate these norms.'

However, such contradictory legitimation practices have implications for overall assessments of the UN's legitimacy: if behaviour appropriate to one side of the UN's identity conflicts with behaviour appropriate to the other, then the many audiences that judge the UN's legitimacy are likely to view the organization not as legitimate but instead inconsistent, arbitrary, and even hypocritical. This is particularly the case because the UN appears to undertake such contradictory discursive and operational practices with little analysis of what type of legitimacy is valued by its various legitimacy audiences.

In this section, I examine how the conflicts between the UN's discourse and practices in peacekeeping affect legitimacy judgments on the part of one audience: the population of the host country in Congo. Within this group, I look at two broad categories - political elites 
and the general population as represented by civil society, academics, and journalists - during the period 2003-10. ${ }^{32}$ This subdivision does not, of course, capture the variety and heterogeneity of this group and the many different concerns, priorities, and viewpoints that people have, but this simple dichotomy serves to demonstrate heuristically how different audiences in peacekeeping settings prize different sources of legitimacy and how contradictions in the UN's legitimation practices undercut their overall judgments of the UN's legitimacy.

For Congo's political elites the UN's legitimacy derived from both how things were done-as they sought to maximize their own control and participation in post-conflict reconstruction and political development - and what was done, with elites often demanding and indeed expecting the rapid disarmament, demobilization, and reintegration (DDR) of forces, reconstruction of roads and other key infrastructure, and holding of elections. Of 13 in-depth interviews with government officials, senior politicians, and military officers, all felt that it was the UN's job to deliver concrete results in terms of security, elections, and socioeconomic well-being. They argued that the UN had both the financial and human resources and the technical expertise to deliver these kinds of substantive outputs, and they expressed not only an expectation, but a sense of entitlement to those resources. At the same time, they rejected any suggestion that the UN should also be in charge of managing such projects and stressed that the UN must leave decisions about the timing, location, and nature of those undertakings to them-in short, that they should be self-determined.

As shown, however, where the UN behaves unilaterally in order to achieve quick results in the short-term and generate output legitimacy, it usually does not do so in any participatory way that preserves host-country self-determination and generates procedural legitimacy. Indeed, all but two interviewees who made no comment on the matter felt that the UN had failed to sufficiently include the Congolese in the processes of decision-making, setting of goals, and monitoring of implementation of mission activities, and several pointed out that for all its talk of inclusion, it generally failed to ensure a substantive role for Congolese. One declared that 'the UN comes with fixed ideas of what it wants and imposes that on nationals. ${ }^{33}$ Most others echoed the sentiment of being imposed upon, with one going so far as to describe the UN's presence as 'neo-colonialism' ${ }^{34}$ and one alleging that 'the UN has no capacity for listening and speaks to us like a child. ${ }^{35}$

At the same time, among the 13 elite interviewees, 12 respondents felt that the UN had failed or mostly failed to demonstrate its ability to deliver concrete results with regards to security and only seven felt it had done enough to manage the electoral process, two of its key operational tasks. In this regard, they derided the UN for 'hiding behind' sovereignty and national ownership when justifying poor results and for its focus on following particular procedures aimed at signaling participation and inclusion, even where they slowed down the attainment of results. For example, several blamed the ongoing insecurity in the east of the country on the UN's failure to 'use its Chapter VII mandate ${ }^{36}$ against recalcitrant rebel groups and its insistence instead on slow nationally-led processes of dialogue, stressing that this 'mean[t] that people die[d]. ${ }^{37}$ Several others echoed this, criticizing the UN for 'say[ing] that it cannot intervene between belligerents...that [it doesn't] have the mandate ${ }^{38}$ and one noting that 'if the UN eradicated the FDLR [a rebel group comprising ex-génocidaires from Rwanda], it would gain a lot of credibility' but pointing out instead that the mission always emphasized that removal of the FDLR must be a national decision. ${ }^{39}$ Another declared that the UN 'has the money, resources, and mandate,' but 'it hasn't managed to fulfill [its] mandate. ${ }^{40}$ In this way, perceptions of illegitimacy derived from the UN's failure to deliver on outputs and its discursive focus on procedure.

The views of the broader population, as represented through civil society representatives, journalists, parliamentarians, and academics, were somewhat different. They 
expressed only vague interest in procedures and were first and foremost concerned with outputs, and their assessments of the UN's legitimacy derived nearly entirely from the latter. As one researcher summed it up, "[t]he views of the population on MONUC are based on results on the ground, not high-level ownership or partnerships. ${ }^{41}$ It thus would appear that the population might be more accepting of a neglect of principles and norms than elites or at least that this would not damage their perceptions of the UN's legitimacy. However, the UN's focus on outputs also raised expectations among the population that they could expect results quickly and regularly across a range of issue areas, which the UN was ultimately unable to deliver, as just described. One analyst asserted that the mission 'do[es] not build anything for the population, nothing permanent, ${ }^{, 42}$ and another noted that ' $[\mathrm{w}]$ hat the population needs is development, but the UN seems to just waste money. ${ }^{43}$ On the provision of security, popular views echoed elite disappointment with the UN's record, with one civil society representative stating that "people [feel] the UN [is] here to count the dead instead of to prevent [security incidents] from happening in the first place. ${ }^{44}$

In addition, even if the population did not view inclusive and nationally-led processes as a primary source of legitimacy, it was not unaware of the UN's rhetoric in this regard. As a result, the UN was generally viewed as contradictory and confusing rather than efficient and helpful. One civil society representative noted that 'there is a lot of suspicion of MONUC. ${ }^{45}$ Another alleged that 'only a quarter of the population knows what the UN is doing, ${ }^{, 46}$ while yet another reiterated the popular confusion about mission goals and added that, as a result, 'the population feels that MONUC is not with them and for them. ${ }^{47}$ One noted bluntly that, ' $[\mathrm{t}]$ he population does not like the UN's rhetoric,' suggesting that the gap between its discourse and its practices was not lost on the population, and that its contradictory discourse and practices had deleterious effects on their overall assessments of its legitimacy. ${ }^{48}$

As can be seen, different audiences - and here only two have been analysed - are

interested in different types of legitimacy, and these are likely to vary further over time. ${ }^{49}$ Yet the UN tends to undertake practices of legitimation intended to demonstrate its legitimacy to these audiences with little dedicated analysis of how each one conceives of legitimacy. This, together with the fact that its legitimation practices often contradict one another, thus usually reduce its legitimacy in the eyes of these audiences for failing to show a coherent approach and for, at least sometimes, misjudging their concerns and priorities. Indeed, the UN's legitimacy deficit in Congo was clear, with a majority of interviewees declaring the UN's rhetoric and its actions were inconsistent and calling the UN 'hypocritical ${ }^{, 50}$ and 'theatrical. ${ }^{, 51}$ In other words, the attempt to generate both procedural and output legitimacy in peace operations may ultimately inhibit the generation of either because most legitimacy audiences are aware of the discrepancy between the UN's rhetoric and its actions, which leads to perceptions of inconsistency, unpredictability, and unreliability. In short, the UN's balancing act appears to fail, and it is unable to fully reaffirm either of its identities through legitimation.

\section{Conclusion}

In a 2015 op-ed in The Telegraph, Mark Malloch-Brown, former Deputy SecretaryGeneral under Kofi Annan, decried 'the heavy bureaucracy, the risk aversion and too often, the apparent abandonment of the exciting founding principles of peace, justice and human development that were intended to animate the UN's activities'; in the same article, he also noted that the UN is highly 'adaptable and nimble,' has been far ahead of its time in terms of addressing new issues such as HIV/AIDS, and has never been afraid to tackle some of the globe's most difficult problems, such as poverty and unequal socio-economic development. The UN stands for both principles and actions, and while in many ways it fails on both 
counts, it also does remarkably well. In short, the UN is characterized by contradiction and inconsistency; indeed, its contradictory nature is in some ways its defining quality.

This contradictory nature is particularly apparent in the UN's peacekeeping operations. As a result and as described in this article, simplistic assessments of whether UN peacekeeping operations are or are not legitimate miss out on a number of key elements, including the fact that legitimacy is a contested and variable concept, one that is understood in different ways by different actors, and one that is claimed or sought in different ways. Because the UN as an organization faces conflicting operational and normative imperatives in peacekeeping - imperatives based on its dual normative and operational identities - it derives legitimacy from a variety of sources, most importantly procedural legitimacy and output legitimacy, which are based, respectively, on whether the organization's behaviour is in line with key institutional norms and principles and on what it achieves and how efficiently.

However, because the UN's normative and operational identities come into conflict in the context of peacekeeping, so too do its legitimation efforts. Its efforts to seek procedural legitimacy through discourse, communication, and the symbolic inclusion of national actors, which are intended to demonstrate behaviour in line with the principles of self-determination and non-interference, and its efforts to seek output legitimacy through efficient if at times exclusive and unilateral action, which are intended to deliver on stated goals and targets, lead to a contradiction between its discourse and its practices. In the case of the host country population, these contradictory discursive and operational practices limit the effectiveness of the UN's legitimation efforts and damage their overall perceptions of the UN's legitimacy. It would not be surprising if the same were true, to varying degrees, for other legitimacy audiences in UN peacekeeping, such as TCCs, donors, and the Security Council.

In an ideal situation, an actor or organization would not face contradictions that limit its ability to engage in legitimation - that is, the 'right' way to do something would also be the most efficient, thus enabling the actor to behave in line with all sides of its identity and satisfy various legitimacy criteria simultaneously. Indeed, the clash between output and procedural legitimacy need not inherently reduce overall legitimacy. As discussed, actors can retain legitimacy even where certain actions go against stated principles and, in selected instances, violation of principles in the interests of a particular output may be encouraged and applauded. However, as shown, I have found that the UN's contradictory legitimation practices - and more broadly contradictions between procedural and output legitimacy in peacekeeping - lead to reduced perceptions of legitimacy, at least on the part of the local population. Ultimately, in the complex context of international peace operations, it appears that the UN's dual identity is not something that can be overcome. Lipson $(2007,22)$ argues that policies and practices that 'enhance an organization's capacity to efficiently produce coordinated action may deprive it of the capacity to function as a political organization,' and the converse is also true; in this sense, legitimacy types appear to be zero-sum because they would compel the UN to negate or eliminate one of its identities.

In this way, it is likely that UN peacekeeping operations will always suffer from some degree of legitimacy deficit - depending on the type of legitimacy and the audience in question. The UN's attempts to balance between different types of legitimacy then should not be judged too harshly. While the UN could stand to pay closer attention to the particular legitimacy concerns of different audiences and could potentially generate greater perceptions of legitimacy if it tailored its legitimation efforts more specifically, it will always have to engage in varying and contradictory legitimation practices, a reflection of the inherent tensions within the practice of peacekeeping and within its identity as an organization.

\section{References}


Barker, Rodney. 2001. Legitimating Identities: The Self-Presentations of Rulers and Subjects. Cambridge: Cambridge University Press.

Barnett, Michael, and Martha Finnemore. 2004. Rules for the World: International Organizations in Global Politics. Ithaca: Cornell University Press.

Beetham, David. 1991. The Legitimation of Power. Basingstoke: MacMillan.

von Billerbeck, Sarah B. K. 2015. 'Local Ownership and UN Peacebuilding: Discourse Versus Operationalization,' Global Governance 21 (2): 299-315.

von Billerbeck, Sarah B. K. 2016. Whose Peace? Local Ownership and United Nations Peacekeeping. Oxford: Oxford University Press.

von Billerbeck, Sarah B. K. and Birte J. Gippert. 2017. 'Legitimacy in Conflict: Concepts, Practices, Challenges - Introduction to Special Issue.' Journal of Intervention and Statebuilding 11 (3): $\mathrm{xxx}-\mathrm{xxx}$.

Brunsson, Nils. 2002. The Organization of Hypocrisy: Talk, Decisions and Actions in Organizations. $2^{\text {nd }}$ ed. Translated by Nancy Adler. Oslo: Abstrakt Forlag.

Cassese, Antonio. 1995. Self-Determination of Peoples: A Legal Reappraisal. Cambridge: Cambridge University Press.

Chandler, David. 2006. Empire in Denial: The Politics of State-building. London: Pluto.

Chesterman, Simon. 2007. 'Ownership in Theory and in Practice: Transfer of Authority in UN Statebuilding Operations,' Journal of Intervention and Statebuilding 1 (1): 3-26.

Clark, Ian. 2005. Legitimacy in International Society. Oxford: Oxford University Press.

Claude, Inis L., Jr. 1966. 'Collective Legitimization as a Political Function of the United Nations.' International Organization 20 (3): 367-379.

Coicaud, Jean-Marc. 2002. Legitimacy and Politics: A Contribution to the Study of Political Right and Political Responsibility, translated by David Ames Curtis. Cambridge: Cambridge University Press.

Coleman, Katharina P. 2007. International Organisations and Peace Enforcement: The Politics of International Legitimacy. New York: Cambridge University Press.

Coleman, Katharina P. 2017. 'The Legitimacy Audience Shapes the Coalition: Lessons from Afghanistan, 2001.' Journal of Intervention and Statebuilding 11 (3): xxx-Xxx.

Donais, Timothy. 2009. 'Empowerment or Imposition? Dilemmas of Local Ownership in Post-Conflict Peacebuilding Processes.' Peace and Change 34 (1): 3-26.

Easton, David. 1965. A Systems Analysis of Political Life. Wiley.

Easton, David. 1975. A Re-Assessment of the Concept of Political Support.' British Journal of Political Science 5 (4): 435-57. 
Edelstein, David M. 2009. 'Foreign Militaries, Sustainable Institutions, and Postwar Statebuilding.' In The Dilemmas of Statebuilding: Confronting the Contradictions of Postwar Peace Operations, edited by Roland Paris and Timothy Sisk, 81-103.

Edomwonyi, Oghogho. 2003. 'Rwanda: The Importance of Local Ownership of the PostConflict Reconstruction Process.' Conflict Trends (African Centre for Constructive Resolution of Disputes) 4: 43-47.

Franck, Thomas M. 1990. The Power of Legitimacy Among Nations. Oxford: Oxford University Press.

Friedman, Jonathan. 2011. 'Building Civilian Police Capacity: Post-Conflict Liberia, 20032011.' Policy Note 176, Innovations for Successful Societies, Princeton University.

Gilley, Bruce. 2009. The Right to Rule: How States Win and Lose Legitimacy. New York: Columbia University Press.

Goldmann, Kjell. 2005. 'Appropriateness and Consequences: The Logic of NeoInstitutionalism,' Governance: An International Journal of Policy, Administration, and Institutions 18 (1): 35-52.

Gow, James, and Christopher Dandeker. 1995. 'Peace-Support Operations: The Problem of Legitimation,' The World Today 51 (8/9): 171-174.

Hannum, Hurst. .1990 Autonomy, Sovereignty, and Self-Determination: The Accommodation of Conflicting Rights. Philadelphia: University of Pennsylvania Press.

Hurd, Ian. 2001. 'Legitimacy, Power, and the Symbolic Life of the UN Security Council,' Global Governance 8: 35-51.

Hurd, Ian. 2007. After Anarchy: Legitimacy and Power in the United Nations Security Council. Princeton, NJ: Princeton University Press.

Krasner, Stephen D. 1999. Sovereignty: Organized Hypocrisy. Princeton, NY: Princeton University Press.

Lipson, Michael. 2007. 'Peacekeeping: Organized Hypocrisy?' European Journal of International Relations 13 (1): 5-34.

Malloch Brown, Mark. 2015. 'The UN is an Under-Funded Bureaucratic Labyrinth - and a Force for Good in the World.' The Telegraph. June 26.

http://www.telegraph.co.uk/news/worldnews/11699243/The-UN-is-an-under-fundedbureaucratic-labyrinth-and-a-force-for-good-in-the-world.html.

March, James G. and Johan P. Olsen. 1998. 'The Institutional Dynamics of International Political Orders,' International Organization 52 (4): 943-969. 
McDowell, Christopher. 2006. 'Displacement, Return, and Justice in the Creation of Timor Leste.' In Catching Fire: Containing Forced Migration in a Volatile World, edited by Nicholas Van Hear and Christopher McDowell, 181-211. Lanham, MD: Lexington Books.

Mersiades, Michael. 2005. 'Peacekeeping and Legitimacy: Lessons from Cambodia and Somalia,' International Peacekeeping 12, no. 2: 205-221.

Mulligan, Shane P. 2005. 'The Uses of Legitimacy in International Relations,' Millennium Journal of International Studies 34 (2): 349-375.

Nsia-Pepra, Kofi. 2014. UN Robust Peacekeeping: Civilian Protection in Violent Civil Wars. New York: Palgrave Macmillan.

Ocran, T. Modibo. 2002. 'The Doctrine of Humanitarian Intervention in Light of Robust Peacekeeping,' Boston College International and Comparative Law Review 25 (1): 1-58.

Paris, Roland, and Timothy D. Sisk, eds. 2009. The Dilemmas of Statebuilding: Confronting the Contradictions of Postwar Peace Operations. Abingdon: Routledge.

Pouligny, Béatrice. 2006. Peace Operations Seen from Below: UN Missions and Local People. London: Hurst and Co.

Richmond, Oliver P. 2004. 'UN Peace Operations and the Dilemmas of the Peacebuilding Consensus.' International Peacekeeping 11 (1): 83-101.

Roberts, Adam. 2003. 'Law and the Use of Force After Iraq,' Survival 45 (2): 31-56.

Rubinstein, Robert A. 2008. Peacekeeping Under Fire: Culture and Intervention. Abingdon, UK: Paradigm Publishers.

Saul, Matthew. 2011. 'Local Ownership of Post-Conflict Reconstruction in International Law: The Initiation of International Involvement.' Journal of Conflict and Security Law 16 (1): 165-206.

Scharpf, Fritz Wilhelm. 1999. Governing in Europe: Effective and Democratic? Oxford: Oxford University Press.

Schmidt, Vivien. 2010. 'Democracy and Legitimacy in the European Union Revisited: Input, Output and Throughput.' Freie Universität Berlin Kolleg-Forschergruppe Working Paper 21.

Sedra, Mark. 2006. 'Security Sector Reform in Afghanistan: The Slide Towards Expediency.' International Peacekeeping 13 (1): 94-110.

Steffek, Jens. 2003. 'The Legitimation of International Governance: A Discourse Approach,' European Journal of International Relations 9 (2): 249-275.

Suchman, Mark C. 1995. 'Managing Legitimacy: Strategic and Institutional Approaches,' Academy of Management Review 20 (3): 571-610. 
UN (United Nations). 2002. 'East Timor - UNTAET: Background.' Accessed 11 April 2016. http://www.un.org/en/peacekeeping/missions/past/etimor/UntaetB.htm.

UN (United Nations). 2003. Handbook on United Nations Multidimensional Peacekeeping Operations. New York: United Nations, Department of Peacekeeping Operations, Best Practices Unit.

UN (United Nations). 2004. The Rule of Law and Transitional Justice in Conflict and PostConflict Societies, S/2004/616. August 23.

UN (United Nations). 2008. United Nations Peacekeeping Operations: Principles and Guidelines (Capstone Doctrine). New York: United Nations, Department of Peacekeeping Operations, Department of Policy, Evaluation and Training.

UN (United Nations). 2009. Report of the Secretary-General on Peacebuilding in the Immediate Aftermath of Conflict. A/63/881-S/2009/304.

UN (United Nations). 2011. Proces-Verbaux of $6630^{\text {th }}$ Meeting [provisional]: Maintenance of International Peace and Security, S/PV.6630. October 12.

UN (United Nations). 2015. Report of the High-Level Independent Panel on Peace Operations on Uniting our Strengths for Peace: Politics, Partnership and People, A/70/95S/2015/446. June 17.

UN (United Nations). N.d. 'Advisory Committee on Administrative and Budgetary Questions: Peacekeeping.' Accessed 12 April 2016.

https://www.un.org/ga/acabq/subjects/510.

Weber, Max. 1978. Economy and Society. Edited by Guenther Roth and Claus Wittich. Berkeley: University of California Press.

Weigand, Florian. 2015. 'Investigating the Role of Legitimacy in the Political Order of Conflict-torn Spaces.' Security in Transition Working Paper, SiT/WP/04/15.

Whalan, Jeni. 2013. How Peace Operations Work: Power Legitimacy, and Effectiveness. Oxford: Oxford University Press.

Whalan, Jeni. 2017. 'The Local Legitimacy of Peacekeepers.' Journal of Intervention and Statebuilding 11 (3): $\mathrm{xxx}-\mathrm{xxx}$.

Wiharta, Sharon. 2009. 'The Legitimacy of Peace Operations.' In SIPRI Yearbook 2009: Armaments, Disarmament and International Security, 95-116. Oxford: Oxford University Press.

Wilde, Ralph. 2012. 'Competing Normative Visions of Exit,' in Exit Strategies and State Building, edited by Richard Caplan, PAGES. New York: Oxford University Press.

Wilén, Nina. 2009. 'Capacity-Building or Capacity-Taking? Legitimizing Concepts in Peace and Development Operations.’ International Peacekeeping 16 (3): 337-351. 
${ }^{1}$ Some emphasize the need to justify the presence of peacekeepers because of what they describe as a dangerous similarity to colonialism or imperialism (see, for example, Richmond 2004; Chandler 2006). Others focus on the distinction between the legality and morality of intervention, noting that the two do not always go hand in hand (see, for example, Nsia-Pepra 2014; Ocran 2002).

${ }^{2}$ These are the Mission de l'Organisation des Nations Unies en Congo (MONUC), the UN Mission in Liberia (UNMIL), and the Integrated Mission in East Timor (UNMIT).

${ }^{3}$ The UN is a vast and varied organization and can rarely be characterized in a way that captures all of its diversity; however, for expediency I here refer to the Department of Peacekeeping Operations (DPKO) and its field missions as the UN. This does not, however, reflect a belief that the organization is monolithic in any way.

${ }^{4}$ A total of 74 interviews were conducted between November 2009 and January 2012 in New York, Geneva, London, and Kinshasa. One-to-one interviews are particularly effective in gauging perceptions and in enabling interviewees to speak openly; they were also feasible in terms of logistics, access, research ethics, and security.

${ }^{5}$ Numerous typologies of legitimacy exist. Weber (1978) famously posited three sources of political legitimacy: rational legality, tradition, and charisma. Scharpf (1999) distinguishes between input and output legitimacy, where the former is similar to procedural legitimacy and emphasizes the participatory nature of processes. Vivien Schmidt (2010) added throughput legitimacy to this, which is similar to procedural legitimacy in that it emphasizes 'the accountability, transparency and efficiency of...decision-making processes along with [an] openness to pluralist consultation' (5). Weigand (2015) juxtaposes instrumental and substantive legitimacy, with the latter focusing on effectiveness, much like Scharpf's output legitimacy. Easton $(1965,1975)$, while not discussing sources of legitimacy per se, distinguishes between diffuse and specific support, where the former entails an ongoing belief in the legitimacy of an actor to fill a certain role and the latter derives from the delivery of outputs that satisfy particular demands, and is thus very similar to output legitimacy. ${ }^{6}$ There are a variety of definitions of self-determination, both legal and political. Here, I use a political definition that conceives of self-determination as the opposite of external or foreign determination of a polity in relation to the population of the country in its entirety, but does not emphasize the self-determination of sub-national groups (Hannum 1990; Cassesse 1995; Saul 2011; Wilde 2012).

${ }^{7}$ The orthodoxy that surrounds local ownership in contemporary peace operations is further evidence of this conviction. Local ownership is construed 'not only as a moral imperative but also as a pragmatic necessity for legitimacy and sustainability' (UN 2011, 2; see also Edomwonyi 2003; Donais 2009; von Billerbeck 2015).

${ }^{8}$ The building of peace is, of course, also a normative activity, not a purely operational one, particularly in light of the liberal content of much of what the UN seeks to achieve in its peacekeeping operations - democratization of the host state, liberalization of institutions, transparency of political processes, and so on. However, the liberal content of peacekeeping is likewise not purely normative, but also partly operational, as democracy and liberal governance are seen as protections against future conflict. The emphasis on them is thus only partly based on a belief that they are 'right' and partly on a belief that they will help to stabilize the host country. This, combined with the fact that peace and stability are the primary mandated goals of a peacekeeping operation, are why I conceive of peace here as an operational goal.

${ }^{9}$ There are, of course, other principles and outputs that concern these two sides of the UN, but in the context of peace operations, the dichotomy between self-determination and keeping 
the peace is the most salient because they conflict with one another and thus this distinction retains analytical utility. Moreover, because self-determination and keeping the peace are broad categories, a number of more specific principles and outputs are subsumed within them, such as, for example, equality before the law, public participation, and security sector reform, thus demonstrating that they are not absolute.

${ }^{10}$ Though it can be more difficult to demonstrate that these are actually intended as legitimation practices, as opposed to simply engaging in mandated tasks, as shall be shown later, UN staff are highly aware of the need to demonstrate concrete outputs in order to secure legitimacy from audiences.

${ }^{11}$ Interview with senior UN official, New York, November 2009.

${ }^{12}$ Interview with senior MONUC official, New York, December 2010.

${ }^{13}$ Interviews with DPKO official, New York, November 2009, and senior DPKO/UNDP official, Geneva, May 2011.

${ }^{14}$ Interview with UN official, New York, November 2009.

${ }^{15}$ Interview with UN official, New York, November 2009.

${ }^{16}$ Interview with senior DPKO official, New York, December 2010.

${ }^{17}$ These missions included the UN Transitional Administration in East Timor (UNTAET) 1999-2002, the UN Mission of Support in East Timor (UNMISET) 2002-5, and UNMIT 2006-2012.

${ }^{18}$ East Timor's dependence on external support for the maintenance of security was most blatantly demonstrated in 2006 when tensions within the military and with the police erupted into violence less than a year after UNMISET left the country.

${ }^{19}$ The UN peacekeeping operation in Congo has been in place from 1999 until the present, first as the MONUC from 1999-2010 and subsequently as the Mission de l'Organisation des Nations Unies pour la Stabilisation en RD Congo (MONUSCO). UNMIL has been in place since 2003.

${ }^{20}$ Interview with former senior UN military commander, London, October 2011.

${ }^{21}$ Interview with senior DPKO official, New York, December 2010.

${ }^{22}$ Interviews with senior DPKO officials, New York, November 2009 and December 2010.

${ }^{23}$ Interview with senior DPKO official, New York, December 2010. Also, interview with senior DPKO official, November 2009.

${ }^{24}$ Interviews with DPKO official, New York, November 2009, and with MONUC official, Kinshasa, March 2011. Mike Sedra (2006) calls this preference for working with elites with regards to security objectives a 'slide towards expediency.'

${ }^{25}$ Interviews with DPKO officials, New York, November 2009.

${ }^{26}$ Interview with DPKO official, New York, November 2009.

${ }^{27}$ Interview with DPKO/former UNMIT official, November 2009.

${ }^{28}$ Interview with senior DPKO/UNDP official, Geneva, May 2011.

${ }^{29}$ The referendum on independence was approved with $78.5 \%$ of the vote, with voter turnout of $98 \%$, reflecting a high degree of unity among the population (UN 2002).

${ }^{30}$ Interview with senior MONUC official, Kinshasa, March 2011.

${ }^{31}$ Interview with MONUC official, New York, December 2010.

${ }^{32}$ This represents the period from the signing of the Global and All-Inclusive Agreement in Sun City, South Africa until the mission changed name to the Mission de Organisation des Nations Unies pour la Stabilisation en RD Congo (MONUSCO).

${ }^{33}$ Interview with senior Congolese government official, Kinshasa, March 2011.

${ }^{34}$ Interview with Congolese government ambassador, Kinshasa, March 2011.

${ }^{35}$ Interview with Congolese government minister, Kinshasa, March 2011.

${ }^{36}$ Interview with Congolese government ambassador, Kinshasa, March 2011. 
${ }^{37}$ Interview with senior Congolese government official, Kinshasa, March 2011.

${ }^{38}$ Interview with Congolese academic, Kinshasa, March 2011.

${ }^{39}$ Interview with Congolese government ambassador, Kinshasa, March 2011.

${ }^{40}$ Interview with Congolese journalist, Kinshasa, March 2011.

${ }^{41}$ Interview with Congolese researcher, Kinshasa, March 2011. One academic described this in a slightly more forgiving way, but with the same assessment for popular views of the UN's legitimacy: "The population wanted the UN to do everything - pacification, peace agreement, ceasefire, respect for human rights, etc. - but with that kind of expectation the UN can never deliver and so they think it did nothing.' Interview with Congolese academic, March 2011.

${ }^{42}$ Interview with Congolese member of parliament, Kinshasa, March 2011.

${ }^{43}$ Interview with Congolese academic, Kinshasa, March 2011.

${ }^{44}$ Interview with Congolese civil society leader, Kinshasa, March 2011.

${ }^{45}$ Interview with Congolese civil society leader, Kinshasa, March 2011.

${ }^{46}$ Interview with Congolese member of parliament, Kinshasa, March 2011.

${ }^{47}$ Interview with Congolese academic, March 2011.

${ }^{48}$ Interview with Congolese academic, March 2011.

${ }^{49}$ While here I have not measured the variance in perceptions over time, it is possible that output might constitute a more important source of legitimacy for all audiences early on in a mission's life span, when the security situation and peace agreement are at their newest and most fragile, with procedural legitimacy becoming more salient later. On the other hand, inclusive processes are important at the drafting of a peace agreement and if security and other deliverables diminish too quickly, resentment against a mission is likely to grow. In this way, any simple linear or inverse relationship may not hold and different sources of legitimacy are likely to ebb and flow on an ongoing basis.

${ }^{50}$ Interviews with Congolese politicians, Kinshasa, March 2011.

${ }^{51}$ Interview with Congolese government ambassador, Kinshasa, March 2011.

\section{Acknowledgments}

My thanks go to my co-editor, Birte Julia Gippert, the editorial team at JISB, participants of the workshop on 'Legitimacy in Conflict' held at the University of Reading in 2014, the anonymous reviewers for their insightful comments and suggestions, and the many people who consented to be interviewed for this project. This work was supported by the Clarendon Fund, Nuffield College, and the Department of Politics and International Relations at the University of Oxford.

\section{Disclosure Statement}

No potential conflict of interest was reported by the author.

\section{Notes on Contributor}

Sarah B. K. von Billerbeck is a Lecturer in Politics and International Relations at the University of Reading, UK. 